DOI 10.14746/ppuam.2019.9.06

\author{
Natalia Cwicinskaja
}

\title{
Crimea and Liability of Russia and Ukraine under the European Convention on the Protection of Human Rights
}

\section{Introduction}

Five years after the events in Crimea is the question "does Crimea now constitute a part of Russia or Ukraine" still valid? Most of the countries and international organizations qualify the Russian actions undertaken in Ukraine as a violation of the norms of international law. ${ }^{1}$ In particular, the Ukrainian side treated Russian actions in Crimea as annexation. ${ }^{2}$ Russia, of course, does not agree with such a view of the issue, and explained the situation as the asserting and exercising of the people's rights to self-determination. ${ }^{3}$ However, as of today, no international courts have decided whether Crimea is Russian or Ukrainian territory under international law. Regardless of how this situation is treated by international law, we are faced with a fait accompli. Russia has complete control over Crimea.

This situation has a direct impact on the residents of the Crimean Peninsula. Since Russia took control over the territory, Crimea's human rights situation has been drastically deteriorating. ${ }^{4}$ The full range of political and civil rights for Crimea's residents are limited by Russian law. Paradoxically, Ukraine also contributes to the violation of individual human rights of the Crimean residents. The international community has little

1 P. Grzebyk, Aneksja Krymu przez Rosje w świetle prawa międzynarodowego, "Sprawy Międzynarodowe” 2014, no. 1, pp. 19-37; J. Kranz, Kilka uwag na tle aneksji Krymu przez Rosje, "Państwo i Prawo" 2014, no. 8, pp. 23-40; T. D. Grant, Aggression Against Ukraine. Territory, Responsibility, and International Law, Palgrave Macmillan 2015; N. Cwicinskaja, Problem legalności secesji Krymu w 2014 r. ws śrietle prawa międzynarodowego, w Rewolucja w imię godności. Ukrainski Euromajdan 2013-2014, eds. G. Skrukwa, M. Studenna-Skrukwa, Wydawnictwo Adam Marszałek 2015, pp. 179-203.

2 N. Cwicinskaja, The Legality and Certain Legal Consequences of the "Accession” of Crimea to the Russian Federation, „Polish Yearbook of International Law, 2014, XXXIV, p. 6668.

3 Ibidem.

4 ReportoftheHumanRightsAssessmentMissionon Crimea6-18July2015, OSCEOfficeforDemocratic Institutions and Human Rights \& High Commisioner on National Minorities. <https://www. osce.org/odihr/report-of-the-human-rights-assessment-mission-on-crimea?download=true $>$. 
access to Crimea, as the authorities have denied or limited travel for representatives of international organisations. It has led to numerous individual applications to the European Court of Human Rights (ECtHR) from Crimea's residents. Applications have been lodged against Ukraine, or Russia, or both. Ukraine is also has brought cases against Russia's actions on its territory in the ECtHR under art. 33 of the European Convention of Human Rights and Fundamental Freedoms (ECHR).

As of the end of 2018, there were over 4,000 individual applications before the Court which are related to the events in Crimea or to the hostilities in Eastern Ukraine and five inter-state applications brought by Ukraine against Russia. One of the inter-state cases related directly to events in Crimea (no. 20958/14). ${ }^{5}$

The ECtHR exercises jurisdiction over a dispute between individual and state or between two states concerning the breach of the provisions of the Convention or its Protocol. The Court's future judgments in cases related to Crimea will point out the responsible state for human rights violations of residents of Crimea. Although the ECtHR has no jurisdiction to determine the legality of Russia's acquisition of Crimea, it is highly likely that during the consideration of the cases it will assess Russia's actions from the point of view of international law.

This article starts with an overview of pending and possible prospective cases originating from the conflict around Crimea between Ukraine and Russia. Individual as well as inter-state applications are presented. The analysing of prospects for complaints filed with the ECtHR and prospective cases is based on the cases already settled by the ECtHR and on ongoing cases of human rights violation of the residents of Crimea. Due to the inconsistency in case law of the ECtHR it is difficult to clearly determine what state will be considered responsible for the violation of the rights of residents of Crimea resulting from the Convention. The possible outcome of applications is proposed based on analysing the ECtHR's law-cases in the next part of the article. The last part provides a summary and offers some conclusions.

\section{Cases Related to the Situation in Crimea Before the ECtHR: Individual Applications}

\section{Lodged Applications}

According to a ECtHR press release from the 17th of December 2018, there are more than 4000 individual cases before the Court with a nexus to the conflict in Eastern Ukraine and Crimea. The Court does not maintain a separate list of complaints related

5 ECHR to adjourn some individual applications on Eastern Ukraine pending Grand Chamber judgment in related inter-State case, Press Release issued by the Registrar of the Court, ECHR 432 2018, 17.12.2018. 
to Crimea and a separate list related to events in Eastern Ukraine. It is difficult to accurately indicate how many complaints specifically concern events in Crimea as of today, e.g., in November 2014 it was more than $20 .{ }^{6}$ In 2016 more than 1170 cases were rejected as the Court found the allegations had not been substantiated ${ }^{7}$.

Up to and as of April 2019 there has been no judgement of the ECtHR related to the situation in Crimea since February 2014. However, some of those cases had been considered by the Court and were communicated. These are: the case of Sentsov against Russia lodged on 7 July 2014 (Application No. 48881/14) ${ }^{8}$ and the case of Sentsov and Kolchenko against Russia lodged on 27 April 2016 (Application No. 29627/16). ${ }^{9}$

In the first case the applicant complains that his arrest and the decision on his detention were arbitrary and violated Article $5 \S 1$ (c) of the ECHR. Further, the applicant complains that he was not brought before a judge established in accordance with the national law and that the decision on his detention was not substantiated. In this case the ECtHR decided on the interim measure, calling the Russian government to provide the applicant with appropriate treatment in an institutionalized medical setting on 25 July $2018 .{ }^{10}$ Measures were decided without prejudging any subsequent decisions on the admissibility or merits of the case. However, the case was communicated to the Russian government less than two months later, on 20 September 2018. Previously, the priority had been given to this application. On the same date the President of the First Section to which the case had been allocated decided to adjourn the Court's proceeding in the case pending the outcome of the proceedings in the inter-state case Ukraine v. Russia (re Crimea) no. 20958/14. ${ }^{11}$ The Russian government was requested to submit observations by 16 January 2019. There were following questions among others: did the applicant come with the jurisdiction of the Russian Federation with the meaning of Article 1 of the Convention interpreted by the Court in some previous cases on the account of the circumstances of the present case? Are the acts of which the applicant complains in the present case imputable to the Russian Federation, within the meaning of Article 34 in conjunction with Article 1 of the Convention? Was the judge who, on 11 May 2014, ordered the applicant's pre-trial detention, a "judge or other officer duly authorised by law to exercise judicial power", within the meaning of Article $5 \S 3$ of the Convention?

Initially, on 16 January 2019, the Russian authorities sent to the ECtHR proposition to postpone the exchange of documents on this application until the outcome of the proceedings in the inter-state case Ukraine v. Russia (re Crimea). The Agency "Intefax" received the

6 Information Note on the Court's Case - Law, No. 179, November 2014, Council of Europe, p. 18.

7 ECHR to adjourn ..., op.cit.

8 Sentsov v Russia, No. 48881/14.

9 Sentsov and Kolchenko v. Russia, No. 29627/16.

10 Court decides on medical care interim measure for Oleg Sentsov, calls on him to end hunger strike, Press Release issued by the Registrar of the Court, ECHR 271 2018, 25.07.2018.

11 First Section, ECHR-LE4.1cR OBS CHB, 26/09/2018. 
official position of the Russian Ministry of Justice: "In connection with the notification of the European Court of Human Rights about the adjournment of the proceedings in the 'Sentsov v. Russia' complaint before the outcome of the proceedings in the case of 'Ukraine v. Russia (re Crimea)', the Russian authorities sent a position on the inexpediency of the exchange of procedural documents on admissibility and merits before making decisions on the admissibility of the abovementioned intergovernmental complaint, given that the findings of the ECtHR in this decision can significantly affect the content of the legal positions of the parties on the individual complaint". ${ }^{12}$ However, on 13 March 2019, some news agencies published information that the Russian authorities had sent their observations to the ECtHR. Russia has provided the affirmative answer to the questions posed by the Court. The memorandum of Mikhail Galperin, Russian Federation's Representative at the ECtHR, states that since March 18, Russia exercises jurisdiction in the territory of the Republic of Crimea and is responsible for all actions of state bodies. Sentsov was arrested in connection with suspicion of committing a crime, and these suspicions proved to be reasonable. As for the judge of the district court of Simferopol Denis Didenko, at the time of the decision he was the acting judge of the Russian court on the basis of the Law "On the acceptance into Russian Federation of the Republic of Crimea", adopted on 21 March 2014. ${ }^{13}$

The second case refers the conviction of Ukrainian citizens by Russian courts for terrorism committed in Crimea after its annexation. Applicants complain that under Article 6 $\S 1$ they were not brought before a tribunal established by law. In their opinion since the annexation of Crimea was unlawful and since they were Ukrainian citizens and the alleged crimes were committed on Ukrainian territory (in Crimea) they could not have been tried by a Russian court. Further they complain that their trial was unfair as they were convicted on the basis of evidence obtained by torture and coercion and their conviction was not based on relevant and sufficient evidence. The case was communicated to the Russian government on 19 November 2018. There are five questions to the parties. Most of them concerned the evidence and inhuman or degrading treatment of one of the applicants. But one of the questions concerned the court before which the case of applicants was conducted. The ECtHR asked the Russian government a detailed question - was the court, which dealt with the applicant's case, a tribunal established by law, as required by Article $6 \S 1$ of the Convention? Until 9 April 2019 there is no information about the responses provided by the Russian government. However, considering the observation given by the Russian Federation in the Sentsov v. Russia case, one should also expect an affirmative answer to this question.

However, there is no further consideration of both cases by the ECtHR to expect in the near future. According to the Information Agency UNN, it received the notifica-

12 Rossija ne napravila v ESPC dokumenty po delu Sentsova-SMI, 17 January 2019. <https:// ru.krymr.com/a/news-oleg-sencov-evropeyskiy-sud-po-pravam-cheloveka/29715614.html>.

13 A. Kornia, Rossija otvetila na voprosy ESPC po jalobe ukrainskogo rejisera Sentsova, Vedomosti <https:/www.vedomosti.ru/politics/articles/2019/03/13/796360-rossiya-otvetila-na-voprosi-espch>. 
tion from the ECtHR Press Service, that "[...] this case is still adjourned until the outcome of the proceedings in the case Ukraine v. Russia (in relation to the Crimea) no. $20958 / 14 ” .14$

\section{Prospective Complaints}

According to numerous human rights protection organisations, Russia is perpetrating grave human rights violations against residents of Crimea. ${ }^{15}$ The scale of human rights violations allows to consider that the number of applications brought to this moment to the ECtHR does not exhaust all possible complaints and may gradually increase. The indefinite, controversial status of Crimea additionally has a negative impact on the ability of citizens to exercise their rights. Formally Ukraine bears responsibility for the observance of human rights in Crimea, however, de facto, Crimea is a part of Russia now. Obviously, under the international law, the Russian Federation, as the occupying state, bears the main responsibility for the human rights violations in Crimea. At the same time, there are areas, where Ukraine could be responsible under the ECHR. Numerous situations described in the media or in reports of non-governmental and international organisations could be used to draw up a complaint to the ECtHR. The framework of the article does not allow analysing violations of all human rights guaranteed by the ECHR. Only one of them, regarding the violation of the freedom of movement, will be presented to describe the possibility of drawing up complaints to the ECtHR.

\section{Freedom of Movement (Art. 2 of Protocol No. 4)}

Pursuant to the Federal Constitutional Law of 21.03.2014 No. 6 -FKZ "On acceptance of the Republic of Crimea into the Russian Federation and the creation of new constituent entities of the Russian Federation - the Republic of Crimea and the Federal City of Sevastopol", the border of the Republic of Crimea on land, interfaced with the territory of Ukraine, is the state border of the Russian Federation ${ }^{16}$. The Federal Migration Service of the Russian Federation announced the establishment of the state border between the

14 S. Karter, Delo Sentsova i Kolchenko v ESPCH vsio esio otlojeno, Informacionnoe Agentstvo UNN, 30.01.2019 <https://www.unn.com.ua/ru/exclusive/1776841-spravu-sentsova -i-kolchenka-v-yespl-vse-sche-vidkladeno>.

15 See widely, Ukraine. Events of 2018, Human Rights Watch <https://www.hrw.org/world-report/2019/country-chapters/ukraine>; Situation of human rights in the temporarily occupied $A u-$ tonomous Republic of Crimea and the City of Sevastopol (Ukraine), Office of the United Nations High Commisioner for Human Rights <https://reliefweb.int/sites/reliefweb.int/files/resources/Crimea2014_2017_EN-1.pdf>.

16 Federalnyi konstitutsionnyi zakon ot 21.03.2014, no. 6-FKZ, O prinyatii v Rossiiskuyu Federatsiyu Respubliki Krym i obrazovanii v sostave Rossiiskoi Federatsii novykh sub'ektov - Respubliki Krym i goroda federalnogo znacheniya Sevastopolya. <http://base.garant.ru/184002/>. 
Crimea and Ukraine only on 25 April 2014. ${ }^{17}$ Ukraine established their crossing point at the administrative boundary line between Crimea and Kherson region already in March 2014. ${ }^{18}$ The establishment of this border has adversely affected the freedom of movement between mainland Ukraine and Crimea. ${ }^{19}$ Besides that, citizens of Ukraine have been deported from Crimea for violating Russian Federation immigration rules. In accordance with the provisions of Article 5 of the Federal Law of July 25, 2002 No. 115-FZ "On the Legal Status of Foreign Citizens in the Russian Federation", if the stay does not require a visa, a foreigner may stay in Russia without registration for 90 days during every 180 days. ${ }^{20}$ These provisions now are applied also in regard to non-Russian citizens, who prior to the occupation, resided in Crimea. This especially applies to individuals who criticize the human rights situation in Crimea. Courts operating in the peninsula found these individuals to be foreigners who violated immigration rules by exceeding the authorized 90-day period in Crimea and ordered their administrative expulsion. However, the application of a given law to such persons is doubtful: this law provides restriction to foreigners who enter Russia, but it doesn't contain a provision which could be applied to persons who became foreigners as a result of occupation. In addition, deportation of those individuals contravenes the provisions of Art. 49 of the Geneva Convention (IV) applying to protected persons in situations of occupation. ${ }^{21} \mathrm{Natu}-$ rally, the Russian Federation does not treat the Crimean status as occupation and will prove that those persons were foreigners under the Russian law. When constructing a complaint to the ECtHR, it is necessary to exhaust effective remedies available at the national level. The decision on expulsion must be appealed and after the court decision of last resort will be rendered, a complaint to the ECtHR could be brought. A similar situation also occurs when the Russian authorities issue a ban on entering the territory of the Russian Federation to persons living in the Crimea before March 2014 who have not acquired Russian citizenship. ${ }^{22}$ Such individuals had temporarily left Crimea and then attempted to come back. The decision on ban on entry has to be also appealed in order to file complaint to the ECtHR.

The freedom of movement can also be violated by the Ukrainian Government. Ukraine has imposed restrictions on entry into and exit from Crimea of foreigners and citizens of Ukraine who have not reached 16 years. According to the art. 3 of the Decree of Cabinet of Ministers of

17 FMS objavila ob ustanovlenii gosgranicy mejdu Krymom i Ukrainoj, 25.04.2014. <https://lenta.ru/ news/2014/04/25/granica/>.

18 About border between Crimea and mainland Ukraine v. Freedom of movement across the administrative bundary line with the Crimea, "Thematic Report", 19.06.2015, OSCE, p. 4-5 <https:// www.osce.org/ukraine-smm/165691?download=true >.

19 V. Freedom of movement..., op. cit.

20 Federalnyj zakon ot 25.07.2002, no. 115-FZ, O pravovom polojenii inostrannyh grajdan v Rossiiskoi Federatsii. <https://www.consultant.ru/document/cons_doc_LAW_37868/>.

21 Geneva Convention relative to the protection of civilian persons in time of war of 12 August 1949.

22 E. Andreyuk, P. Gliesche, Crimea: Deportations and forced transfer of the civil population, "The Foreign Policy", 4.12.2017. 
Ukraine „Order of entry into and exit from the temporarily occupied territory of Ukraine” from 4 June 2015, children below 16 years of age, if travelling only with one parent, must have notarized written consent of the other parent. ${ }^{23}$ Crimean residents, which have documents authorised by a state notary officer of the Republic of Crimea, are not permitted to enter mainland Ukraine, as documents issued in Crimea are not recognised in Ukraine. These requirements are contrary to Art. 10 of the Law of Ukraine on ensuring the rights and freedoms of citizens and the legal regime in the temporarily occupied territory of Ukraine, which establishes the free entry and exit from Crimea of all citizens of Ukraine. ${ }^{24}$ According to the Ukrainian Helsinki Human Rights Union, a lawsuit was filed that this Resolution violates the Constitution of Ukraine and other laws, and also contradicts the international obligations of Ukraine. ${ }^{25}$ In case the Ukrainian court will not find the abovementioned provisions unlawful and after exhaustion of effective remedies available in Ukraine, a complaint to the ECtHR could be prepared.

\section{Inter-State Applications}

There are currently five Ukraine v. Russia inter-state applications. Four of them are pending before the Grand Chamber and one of them is pending before a Chamber.

They are:

- Ukraine v. Russia (re Crimea) (application no. 20958/14).

- Ukraine v. Russia (II) (application no. 43800/14) on the alleged abduction of three groups of children in Eastern Ukraine and their temporary transfer to Russia on three occasions between June and August 2014.

- Ukraine v. Russia (re Eastern Ukraine) (no. 8019/16).

- Ukraine v. Russia (VIII) (application no. no. 55855/18) concerning events on the Kerch Strait in November 2018.

- Ukraine v. Russia (VII) (application no. 38334/18) alleging the politically motivated detention and prosecution of Ukrainian nationals on various criminal charges.

The first case Ukraine v. Russia (20958/14) was lodged by Ukraine as inter-state application under Article 33 on March 13, 2014. In this case Ukraine stated that, from February 27, 2014 The Russian Federation had started to exercise effective control over territory of the Autonomous Republic of Crimea and to exercise control over armed separatist groups operating in Eastern Ukraine. Thus, this State began to exercise jurisdiction over the situation which resulted in numerous violations of the European

23 Pro zatverdjennia Poriadku vjezdu na timchasovo okupovanu teritiruju Ukraini ta viezdu z nei, Oficijnyj visnik Ukraini ot 19.06.2015-2015 g., no 46, p. 130, statja 1485, kod akta 77309/2015.

24 Zakon Ukraini Pro zabezpechennia praw i svobod gromadian ta pravovii rejim na timchasovo okupovanii teritorii Ukraini, Oficijnyj visnik Ukraini oficialnoe izdanie ot, 08.05.2014-2014 g., no. 36, p. 35, statja 957, kod akta 72341/2014.

25 Monitorongovyj obzor sutiacii s pravami cheloveka v Krymu. Iuli-Avgust 2015, Krymskaja pravozashitnaja gruppa, p. 18. 
Convention on Human Rights in those territories. Ukraine accused Russia of violating the following articles of the Convention: 2 (right to life), 3 (prohibition of torture and inhuman or degrading treatment), 5 (right to liberty and security), 6 (right to a fair trial), 8 (right to respect for private life), 9 (freedom of religion), 10 (freedom of expression), 11 (freedom of assembly and association), 13 (right to an effective remedy) and 14 (prohibition of discrimination) of the Convention and Article 1 of Protocol No. 1 (protection of property) and Article 2 of Protocol No. 4 (freedom of movement) to the Convention.

The Ukrainian government stated that between March and September 2014, killings of Ukrainians as a result of the illegal annexation of Crimea amounted to a widespread and systematic practice. They are also alleged cases of ill-treatment Crimean population on account of their ethnic origin. The Ukrainian government stated that Ukrainian nationals living in Crimea were automatically recognized as Russian nationals and that pressure was exerted on those who express the wish to remain Ukrainian nationals. It is alleged that property belonging to Ukrainian legal entities were taken by the self-proclaimed authorities of the Crimean Republic, which acts were later approved by Russian legislation. Finally, the applicant government stated that the border between Crimea and Ukraine has led to Ukrainian nationals' entry into Crimea being unlawfully restricted.

Following the introduction of the application on 13 March 2014, the Court decided to apply Rule 39 of the Rules of Court (interim measures), calling upon both Russia and Ukraine to refrain from taking any measures, in particular military action, which might bring about violations of the Convention rights of the civilian population, notably the right to life and prohibition of torture and inhuman or degrading treatment. ${ }^{26}$

On 25 November 2014 the ECtHR invited the Russian Federation within 16 weeks to submit its observations on admissibility and to answer a number of questions, including the question of whether the alleged violations of the Convention fall within the jurisdiction of the Russian Federation within the meaning of Article 2 of the ECHR. ${ }^{27}$ The allotted time was extended twice at the request of the Russian Federation - initially to 25 September $2015^{28}$ and later to 31 December $2015 .{ }^{29}$ As of today, both governments have already submitted their observations on the merits of the cases. ${ }^{30}$

26 Interim measure granted in inter-State case brought by Ukraine against Russia, ECHR 073, 2014, 13.03.2014.

27 European Court of Human Rights deals with cases concerning Crimea and Eastern Ukraine, ECHR 345, 2014, 26.11.2014.

28 European Court of Human Rights extends time allowed for Russia's observations on admissibility of cases concerning Crimea and Eastern Ukraine, Press Release issued by the Registrar of the Court, ECHR 122 (2015), 13.04.2015.

29 European Court of Human Rights communicates to Russia new inter-State case concerning events in Crimea and Eastern Ukraine, Press Release issued by the Registrar of the Court, ECHR 296 (2015), 01.10.2015

30 Grand Chamber to examine four Compaints by Ukraine Against Russia over Crimea and Eastern Ukraine, ECHR 173, 2018, 09.05.2018. 
The next application regarding Crimea was lodged by the government of Ukraine on 27 August 2015 (application no. Ukraine v. Russia 42410/15). It concerns the events in Crimea and eastern Ukraine after September 2014. ${ }^{31}$ Ukraine stated that Russia had exercised and continues to exercise effective control over Crimea and de facto control over Eastern Ukraine. Therefore, Russia is responsible for violations of the ECHR in those regions. Just as in the case 20958/14, Ukraine accused Russia of violating Articles 2 (right to life), 3 (prohibition of torture and inhuman or degrading treatment), 5 (right to liberty and security), 6 (right to a fair trial), 8 (right to respect for private life), 9 (freedom of religion), 10 (freedom of expression), 11 (freedom of assembly and association), 13 (right to an effective remedy) and 14 (prohibition of discrimination) of the Convention and Article 1 of Protocol No. 1 (protection of property) to the Convention. Furthermore, the Ukrainian government relies on Articles 18 (limitation on use of restrictions on rights) of the ECHR and Article 2 of Protocol No. 1 (right to education) and Article 3 of Protocol No. 1 (right to free elections) to the Convention. When it comes to Crimea, Ukraine accused Russia of, among others, the disappearances of members of the Crimean Tatar community and pro-Ukrainian activists in Crimea and their arbitrary arrests, as well as torture and the ill-treatment of civilian and military personnel. On 29 September 2015 the ECtHR invited Russia to submit its observations on the admissibility of that application within 16 weeks. The ECtHR already received Russian's submissions on this application.

On 6 February 2016, the ECtHR decided to divide the first case 20958/14 geographically in order to increase the effectiveness of case processing. All the complaints related to Crimea remained as case no. 20958/14, while complaints related to Eastern Ukraine were put under the application Ukraine v. Russia (V) no. 8019/16. The same rule was applied to the second discussed application no. 42410/15. Since 25 November 2016 all events in Crimea have remained as case no. 42410/15, while those related to Eastern Ukraine were registered as Ukraine v. Russia (VI) no. 70856/16.

In May 2018 the Chamber dealing with the applications decided to relinquish jurisdiction over the case in favour of the Grand Chamber under Article 30 of the ECHR, which decided to join two cases into one - Ukraine v. Russia (application no. 20958/14). Initially the Grand Chamber hearing was scheduled for 27 February 2019. However, it was postponed for an indefinite period. According to leading Russian news agencies, the ECtHR Press Service stated the postponing had been due to organizational reasons. ${ }^{32}$ In opinions of the Russian legal experts, political aspects have a strong influence on this

31 European Court of Human Rights communicates to Russia..., op.cit.

32 V. ESPC otlojil spor Ukrainy s Rossiej na neopredellennyj srok, 7.02.2019 <https://pravo.ru/ news/208867/>; Kornia, ESPC perenes slushanija po delu «Ukraina protiv Rossii» po Krymu na neopredellennyj srok, 6.02.2019 <https://www.vedomosti.ru/politics/articles/2019/02/ 06/793466-ukraina-protiv-rossii>. 
case. ${ }^{33}$ However, Ukrainian new agencies stated that the reasons of the postponement had not been specified. ${ }^{34}$ In turn, the ECtHR did not specify a new date of hearings nor provided the reasons for its postponement.

There was one more inter-state application of Ukraine against Russia, no. 49537/14 regarding events in Crimea. However, it was struck out by the ECtHR in September 2015 after the government of Ukraine informed that it no longer wants to pursue this application as it concerns the same subject matter as the individual application Dzhemilov v. Ukraine and Russia no. 49522/14. ${ }^{35}$ The Russian government also did not object to the application being struck out of the ECtHR's list. Therefore, the ECtHR considered that it is no longer justified to continue the examination of the application.

Other cases are not related to the events in Crimea and hence go beyond the topic of this article.

The inter-state case procedure in ECtHR is a rarity. As of 31 January 2019, only 26 inter-state cases have been filed. ${ }^{36}$ In 10 most recent cases brought by Georgia and Ukraine during the last 12 years, the Russian Federation is the respondent. As it was pointed out above, Ukraine's application concerns Russia's activities in the territory of Ukraine. Georgia's applications against the Russian Federation relate, among others, to the 2008 armed conflict between Georgia and Russia and its aftermath, including the deterioration of the human rights situation along the administrative boundary lines between Georgian-controlled territory and Abkhazia and South Ossetia. ${ }^{37}$

\section{Possible Outcome of the Applications}

As of April 2019, there has been no judgment of the ECtHR related to the situation in Crimea since February 2014. In order to understand what issues are likely to arise in adjudicating and what a possible outcome of the applications lodged, it is necessary to analyse case law of the ECtHR.

The issues of jurisdiction and the imputability of the alleged violation to the actions or omissions of the State concerned will be crucial. A State's jurisdiction within the meaning of Article 1 is essentially territorial. It is presumed to be exercised throughout the State territory. ${ }^{38}$ However, according to the ECtHR, the presumption of territorial jurisdiction may be limited by several exceptional circumstances. Those circumstances are the following: acts of diplomatic or consular agents of the State abroad and on board aircraft and ships registered in that State in accordance with the international law; exercise of

33 Ibidem.

34 ESPC perenes na neopredellenyj srok razbiratelstvo dela „Ukraina protiv Rossii”, 6.02.2019 $<$ https://interfax.com.ua/news/general/564220.html >.

35 Ukraine against Russia, No. 49537/14 24.

36 <https://www.echr.coe.int/Documents/InterStates_applications_ENG.pdf>.

37 New Inter-State application brought by Georgia against Russia, ECHR 287, 2018, 31.08.2018.

38 Assanidze v. Georgia, No. 71503/01, Judgment of 8 April 2004, §137. 
another State's sovereign authority with its agreement; use of force by a State's agents operating outside its territory; exercising State's authority outside its own territory by complete or military occupation of another State, by support for an insurrection or a civil war in another State, by installation or support with installation on the territory of another State of a separatist regime or unrecognised entity; delegation of State powers or its joint exercise with other States $^{39}$.

Judgments in previous cases of the ECtHR related to the Turkish Republic of the Northern Cyprus, Transnistria or Nagorno-Karabakh (de facto regime in ECtHR's terminology) could be relevant to some extent to cases related to Crimea. ${ }^{40}$ The ECtHR developed the following rules:

- the mother State remains the sole legitimate government of the parts of territory which are separate as a result of the third state's unlawful military operations on those territories ${ }^{41}$;

- responsibility of a State arises when as a consequence of military action whether lawful or unlawful - it exercises effective control directly, through its armed forces, or through a subordinate local administration, on the area of another state; ${ }^{42}$

- responsibility of a State arises when as a consequence of the military, economic, financial and political support which it had to provide to the separatist regime established on the territory of another state; ${ }^{43}$

- the State in whose territory a separatist regime has been established may be liable under the Convention, as it has positive obligations to take appropriate steps to ensure that the rights under the Convention are respected within its territory. $^{44}$

However, one should remember that the situation in Crimea is rather different than the situation in the European entities which declared independence and are supported by a third State and are not recognized by the international society (e.g. Northern Cyprus, Transnistria or Nagorno-Karabakh). Crimea now is declaring to be a part of the

39 V. Guide on Article 1 of the European Convention on Human Rights. Obligation to Respect Human Rights - Concepts of "Jurisdiction" and Imputability <https:/www.echr.coe.int/Documents/ Guide_Art_1_ENG.pdf>.

40 One could also mention in this place the cases relating to Ossetia, hovewer as for today, only decision of admissibility on 13 December 2011 was adopted without prejudging the merits of the case. The case is still pending. V. Grand Chamber Hearingin case brought by Georgia against Russia over 2008 conflict, ECHR 183, 2018, 23.05.2018.

41 Cyprus v. Turkey, No. 25781/94, Judgment of 10 May 2001, Para. 61; Ilascu and others v. Moldova and Russia, No 48787/99, Judgment of 8 July 2004, § 330

42 Loisidou v. Turkey, No 15318/89, Judgment of 23 March 1995, Para. 62

43 Ilascu and others v. Moldova and Russia, No 48787/99, Judgment of 8 July 2004, § 392.

44 Ibidem, $\S 313$. 
Russian Federation and is recognised as such by the Russian Federation. In previous cases, the supporting States, such as Turkey, Russia and Armenia, claimed that the actions of the secessionist entities cannot be attributed to them as the entities are independent or are territories which belonged to the mother States. ${ }^{45}$ In the case of Crimea the position of the Russian Federation is quite different. Russia claimed that Crimea belongs to Russia, so actions in Crimea could be attributed to it. Moreover, the Russian Federation also confirmed such a position in its observations in the case Ukraine v. Russia (re Crimea) no. $20958 / 14^{46}$. So, the issue of jurisdiction and the imputability of the alleged violation seems to be relatively clear. However, it seems unlikely that the ECtHR will support the position of the Russian Federation. There is widespread opinion expressed by international organisations that Russian activities in Crimea in March 2014 violated international law and had no legal effect ${ }^{47}$. According to the case law of the ECtHR, there is a probability that the Court will recognise Ukraine as the sole legitimate government of Crimea, like it was done regarding the Republic of Cyprus and the Republic of Moldova in cases Cyprus v. Turkey and Ilascu and Others v. Moldova and Russia.

The question whether Russia is occupying the Ukrainian territory could also arise in adjudicating on Crimean cases. The ECtHR stated in the case of Al-Skeini v United Kingdom that if the territory of State is occupied by the armed forces of another State, the occupying state should in principle be held accountable under the Convention for breaches of human rights within the occupied territory ${ }^{48}$. At the same time in previous cases regarding the Turkish Republic of Northern Cyprus, Transnistria and NagornoKarabakh, the ECtHR seemed to avoid the discussion of problems related to the occupation of Cyprus, Moldova and Azerbaijan ${ }^{49}$. The ECtHR determined only whether the respondent State is responsible for the alleged violation of the rights under the ECHR due to exercised effective control over the concerned territories. There is a probability that in Crimea's case the ECtHR also will limit itself to determining whether Russia

45 Loisidou v. Turkey, No 15318/89, Judgment of 23 March 1995, Para. 54; Ilascu and others v. Moldova and Russia, No 48787/99, Judgment of 8 July 2004, § 354; Chirakov and Others v. Armenia, No. 13216/05, Judgment of 16 June 2015, § 163.

46 Sentsov v Russia, App. No. 48881/14.

47 Resolution 1988 of the Parliamentary Assembly of the Council of Europe, 2014, para 16; Resolution 68/262 of General Assembly of the United Nations adopted on 27 March 2014, A/RES/68/262; Conclusions on Ukraine approved by the European Council 20 March 2014, § 5. 48 Al-Skeini and Others v. United Kingdom, No. 55721/07, Judgment of 7 July 2011, Para 142

49 Cyprus v. Turkey, No. 25781/94, Judgment of 10 May 2001, Ilascu and others v. Moldova and Russia, No 48787/99, Judgment of 8 July 2004, Chirakov and Others v. Armenia, No. 13216/05, Judgment of 16 June 2015. V. H-J. Heintze, On the Relationship Between Human Rights Law Protection and International Humanitarian Law, IRRC, December, 2004, vol. 86, no. 856, pp.805809; M. Milanovic, European Court Decides that Israel is Not Occupying Gasa, EJIL <https:// www.ejiltalk.org/european-court-decides-that-israel-is-not-occupying-gaza/\#more-13413>. 
is exercising effective control over Crimea. This could be sufficient for the ECtHR to indicate Russia's responsibility under the Convention.

In case the ECtHR considers that the Russian Federation exercised effective control over the territory of Crimea, it will examine if acts and the court's decision of Crimean authorities are lawful and valid for the purposes of the ECHR. Such examinations take place at the admissibility stages when the ECtHR decides on the exhaustion of domestic remedies. In previous cases regarding de facto regimes, the ECtHR developed the position according to which legal and judicial systems operating in de facto regimes were not unlawful only because they were established by an unlawful regime $^{50}$. It is significant whether the judicial system in general can be considered compatible with the principles of the Convention..$^{51}$ As it seems that, due to the fact that the Russian law and judicial system operating in reality in Crimea, the law of Crimea will be valid for the purposes of the Convention. The Russian Federation is a member of the ECHR, as well as a member of the Council of Europe, so there should be no doubt about the Crimean legal system.

Does it mean that the Russian Federation would be the only respondent State before the ECtHR? This is not a foregone conclusion. On the one hand, similarly to the case Cyprus v. Turkey, the State (Ukraine) is unable to exercise effective control over a part of territory (Crimea), due to the de facto control of the third State (Russia). On the other side, Ukraine could be obliged to uphold some of its Convention obligations in Crimea, which, in principle, corresponds to the recent ECtHR's jurisprudence regarding separatists' entities and control over them. Such an approach has been applied by the court in the commonly quoted case of Ilascu and Others v. Moldova and Russia. ${ }^{52}$ In addition, in a recent case regarding Karabakh, Sargsyan v. Azerbaijan, the Court found that Azerbaijan had violated rights established in the ECHR, due to the fact that "the Government have failed to discharge the burden of proving the availability to the applicant of a remedy capable of providing redress in respect of his Convention complaints and offering reasonable prospects of success". ${ }^{33}$ Obviously, in the case Sargsyan v Azerbaijan it was disputed that Azerbaijan exercises control over the territory in question, in distinction from the situation that Russia exercises de facto control over Crimea.

50 Cyprus v. Turkey, No. 25781/94, Judgment of 10 May 2001, § 88-90, Demopoulos and Others v. Turkey, No. 46113/99, Decision as to the admissibility, § 94 .

51 Ilascu and others v. Moldova and Russia, No 48787/99, Judgment of 8 July 2004, § 436.

52 "Moldova [...] has a positive obligation under Article 1 of the ECHR to take the diplomatic, economic, judicial or other measures that it is in its power to take and are in accordance with international law to secure to the applicants the rights guaranteed by the ECHR”, Ibidem, §331. Regarding ECtHR's positive obligations case law v. L. Lavrysen, Human Rights in a Positive State. Rethinking the Relationship Between Positive and Negative Obligations under the European Convention on Human Rights, Cambridge - Antwerp - Portland 2016

53 Sargsyan v. Azerbaijan, No. 40167/06, Judgment of 16 June 2015, § 119. 
However, this case may also affect the resolution of cases regarding Ukraine's responsibility for human rights violations in Crimea. So, if an individual brings the case against Ukraine, the ECtHR could apply the concept of positive obligations, which could mean that if Ukraine has to fulfil its obligations under the ECHR concerning residents of Crimea, it has to take measures and efforts to protect rights and freedoms of the residents of Crimea even if it does not control it de facto. The scope of those obligations remains, however, not fully defined and it is difficult to determine what steps Ukraine has to take to fulfil those obligations. ${ }^{54}$

\section{Conclusions}

It could be stated that the issue of the liability of Ukraine and Russia under the ECHR over Crimean residents is not quite clear. Both Russia and Ukraine take actions that violate basic human rights. The ECtHR could determine that the Russian Federation may be held responsible, as it was with Turkey regarding the Northern Cyprus. Also, Ukraine may be considered responsible for human rights violations with respect to Crimean residents. However, as it seems, the liability of Ukraine will be limited to the positive obligations under the ECHR.

Although one should agree with the claim that "the uncertainty surrounding each State's obligations with respect to Crimea is obviously deeply unsatisfactory for both the State and potential victims of human rights abuses" ${ }^{25}$, it is very important, that the ECHR continues to be applied in force on the territory of Crimea. It is reasonable for Crimean residents to lodge complains against both Russia and Ukraine. In previous judgments the ECtHR always has regard to the special character of the Convention as an instrument of the European public order and defined the State which is responsible for violating human rights in order to avoid "a regrettable vacuum in the system of human rights protection" in the specific territory.

\section{Literature}

Cwicinskaja N., Problem legalności secesji Krymu w 2014 r. w świetle prawa międzynarodowego, w Rewolucja w imię godności. Ukrainski Euromajdan 2013-2014, eds. G. Skrukwa, M. Studenna-Skrukwa, Toruń 2015, pp. 179-203.

54 V. S. Wallace, C. Mallory, Applying The European Convention On Human Rights To The Conflict In Ukraine, „Russian Law Journal” 2008, Vol. VI, Issue 3, pp. 38-41.

55 Ibidem, p. 42 
Cwicinskaja N., The Legality and Certain Legal Consequences of the "Accession” of Crimea to the Russian Federation, „Polish Yearbook of International Law, 2014, XXXIV, p. 6668. Grant T. D., Aggression Against Ukraine. Territory, Responsibility, and International Law, Palgrave Macmillan 2015;

Grzebyk P., Aneksja Krymu przez Rosje w świetle prawa międzynarodowego, "Sprawy Międzynarodowe" 2014, no. 1.

Heintze H-J., On the Relationship Between Human Rights Law Protection and International Humanitarian Law, IRRC, December, 2004, vol. 86, no. 856, pp.805-809;

Kranz J., Kilka uwag na tle aneksji Krymu przez Rosje, "Państwo i Prawo" 2014, no. 8, pp. 23-40;

Lavrysen L., Human Rights in a Positive State. Rethinking the Relationship Between Positive and Negative Obligations under the European Convention on Human Rights, Cambridge - Antwerp - Portland 2016

Wallace S., Mallory C., Applying The European Convention On Human Rights To The Confict In Ukraine, „Russian Law Journal” 2008, Vol. VI, Issue 3, pp. 38-41.

$<$ http://base.garant.ru/184002/>.

$<$ https://interfax.com.ua/news/general/564220.html>.

$<$ https://lenta.ru/news/2014/04/25/granica/>.

$<$ https://pravo.ru/news/208867/>; \.Kornia, ESPC perenes slushanija po delu «Ukraina protiv Rossii» po <https://www.vedomosti.ru/politics/ articles/2019/02/06/793466-ukraina-protiv-rossii>.

$<$ https://ru.krymr.com/a/news-oleg-sencov-evropeyskiy-sud-po-pravam-chelove$\mathrm{ka} / 29715614 . \mathrm{html}>$.

$<$ https://www.consultant.ru/document/cons_doc_LAW_37868/>.

$<$ https://www.echr.coe.int/Documents/Guide_Art_1_ENG.pdf>.

$<$ https://www.echr.coe.int/Documents/InterStates_applications_ENG.pdf >.

$<$ https://www.ejiltalk.org/european-court-decides-that-israel-is-not-occupyinggaza/\#more-13413>.

< https://www.hrw.org/world-report/2019/country-chapters/ukraine>; <https://reliefweb.int/sites/reliefweb.int/files/resources/Crimea2014_2017_EN-1.pdf>.

$<$ https://www.osce.org/odihr/report-of-the-human-rights-assessment-mission-oncrimea?download=true $>$.

$<$ https://www.osce.org/ukraine-smm/165691?download=true>.

$<$ https://www.unn.com.ua/ru/exclusive/1776841-spravu-sentsova-i-kolchenka-v-yesplvse-sche-vidkladeno>.

<https://www.vedomosti.ru/politics/articles/2019/03/13/796360-rossiya-otvetila-navoprosi-espch>. 
100 | Adam Mickiewicz University Law Review

SUMMARY

\section{Crimea and Liability of Russia and Ukraine under the European Convention on the Protection of Human Rights}

The aim of this article is to present the liability of Russia and Ukraine regarding Crimea under the European Convention on the Protection of Human Rights. The author analyzes pending and possible prospective cases originating from the conflict around Crimea between Ukraine and Russia. Due to the inconsistency in case law of the ECtHR it is difficult to clearly determine what state will be considered responsible for the violation of the rights of residents of Crimea resulting from the Convention. In author's opinion the ECtHR could determine that the Russian Federation may be held responsible, as well as Ukraine. However, as it seems, the liability of Ukraine will be limited to the positive obligations under the ECHR.

Keywords: Crimea, Ukraine, the Russian Federation, European Convention on the Protection of Human Rights, European Court of Human Rights.

Natalia Cwicinskaja, Adam Mickiewicz University Poznań, Faculty of Law and Administration, A1. Niepodległości 53, 61-714 Poznań, Republic of Poland, e-mail: nc@amu.edu.pl. 